\title{
Determining factors affecting the transition of financial statement preparation from VAS to IFRS in enterprises in Vietnam
}

\author{
Duy Thuc Nguyen ${ }^{a}$, Thi Tha Nghiem ${ }^{b}$, Thanh Long Tran', Duc Hai Nguyen ${ }^{d}$ and Thi Le Hang \\ Nguyen $^{\mathrm{e}^{*}}$
}

${ }^{\mathrm{a}}$ Faculty of Basic Science, Van Lang University, Ho Chi Minh City, Vietnam

${ }^{b}$ Faculty of Corporate Finance, Academy of Finance, Hanoi, Vietnam

${ }^{c}$ Banking Academy, Phu Yen Campus, Phu Yen, Vietnam

${ }^{d}$ Microfinance Centre, Banking Academy, Ha Noi, Vietnam

${ }^{e}$ Faculty of Economics and Accounting, Quy Nhon University, Binh Dinh, Vietnam

\section{CH R O N C L E A B S T R A C T}

Article history:

Received August 26, 2021

Received in revised format

September 292021

Accepted November 162021

Available online

November 162021

Keywords:

Accounting

Enterprises

IFRS

Transition from VAS to IFRS

Vietnam
According to the Ministry of Finance's roadmap for applying IFRS in Vietnam, listed enterprises on the stock market and state-owned enterprises holding the dominant power are the first group of enterprises to alter the preparation of financial statements according to Vietnamese Accounting Standards (VAS) to the application of International Financial Reporting Standards (IFRS). The voluntary application period is from 2022 to 2025 and the period after 2025 will be the mandatory one. This study was conducted to determine the factors affecting the transition from preparing financial statements following VAS to IFRS for this group of enterprises. The study involved surveying managers and chief accountants at 120 enterprises belonging to the group of companies listed on the stock market, state-owned enterprises holding the dominant power, with the adoption of a regression analysis method. The research results show that five factors are affecting the transition of financial reporting from VAS to IFRS in this group of enterprises, with the order of influence being ranked from high to low, respectively as (i) Size and operation characteristics of the enterprise; (ii) Competence of accountants; (iii) Viewpoints of the enterprise administrators; (iv) Applied accounting regime, and (v) Enterprise owners. On that basis, the study proposes some recommendations for the transition from preparing financial statements according to VAS to IFRS for enterprises to meet the Ministry of Finance's roadmap for IFRS application.

\section{Introduction}

Recent studies of Owusu et al. (2017), Ugwu and Udeh (2018), Ajibade et al. (2019) shows that the application of IFRS in the preparation of financial statements of enterprises in countries has a significant impact on attracting foreign investment capital and increasing the value of enterprises in the international market. Therefore, with the trend of integration and convergence with international accounting, creating a legal corridor on accounting to attract enterprises and foreign investors, the Ministry of Finance of Vietnam issued Decision No. 345/ QD-BTC on approving the roadmap to apply IFRS in Vietnam. According to this roadmap, the application of IFRS to enterprises is built in phases, in which certain types of enterprises are entitled to voluntarily register to apply IFRS from 2022 and consider a compulsory application from the year

* Corresponding author.

E-mail address: ntlhang@gnu.edu.vn (T. L. H. Nguyen)

(c) 2022 Growing Science Ltd. All rights reserved.

doi: $10.5267 /$ j.ac.2021.11.003 
2025 (Ministry of Finance, 2016). Since the issuance of the roadmap to apply IFRS in Vietnam, there have been many studies related to determining the factors affecting the application of IFRS in Vietnam, typically those by Tran et al. (2019), Nguyen et al. (2020), Ta et al. (2021), etc. However, most of the studies have been conducted from the perspective of many enterprises or enterprises on the stock market, or enterprises in a group of industries, with the consideration of the impact of factors affecting both inside and outside the enterprises.

Meanwhile, for the listed companies or state-owned enterprises that hold the dominant power, most enterprises when preparing financial statements are producing consolidated financial statements. And when consolidating, the financial statements of subsidiaries, joint ventures and associates (when the company holds more than $50 \%$ of the voting rights according to the agreed regulations), the financial position of the company and business results must be consolidated. At the same time, the studies of Nguyen (2018), Kedzior et al. (2020) It also shows that the transition of financial reporting from national accounting standards to IFRS depends on the similarity of national accounting standards with IFRS, as well as the effort to apply the national accounting standards to IFRS of the enterprise. Therefore, to convert financial statements from VAS to IFRS, the authors believe that will be barriers in terms of operational characteristics and ownership types; or this transition requires the accountants at the parent company and its subsidiaries, joint ventures and associates to have an understanding of IFRS, as well as to have a consensus on how to make accounting records, accounting methods, the participation and direction of administrators at companies, etc.

Stemming from the above issues, this study was conducted to determine the factors affecting the transition of financial reporting from VAS to IFRS from the perspective of considering the combination of the preparation of consolidated financial statements of an enterprise. On that basis, the study proposes policy implications on the conditions that need preparing to make it easier for enterprises to convert financial statements from VAS to IFRS. The structure of the research paper consists of five parts, the following part is the literature review, the third part concerns the research methodology, the fourth part involves the research results, the fifth part revolves around discussion and policy implications, and the sixth part is the conclusion.

\section{Literature Review}

Regarding the identification of factors affecting the application of IFRS in different types of enterprises, there have been many studies conducted both domestically and abroad, typically:

Tran and Nguyen (2016) argue that economic, legal, cultural and political influences have been significant in the application of IFRS in the countries. The study suggests that Vietnam should implement direct solutions to the current national accounting system and focus on factors such as the economy, legal system, educational and cultural level. However, the study is only confined to the previous research synthesis and has not conducted experimental studies for verification.

And there is a study by Do and Tran (2017) which is on the difference in the preparation of financial statements of foreigninvested enterprises according to Vietnamese and international accounting. Research results show that cultural factors affect this difference; accordingly, the authors believe that to reduce the difference to attract foreign investment, state agencies in Vietnam are required to enhance the role of professional accounting organizations in participating in the activities of drafting legal documents in the field of accounting. Nguyen (2018) conducts a study on the method of converting financial statements from VAS to IFRS with an empirical survey of Vietnamese enterprises. The research results show that there are five influencing factors including (i) Economic integration, (ii) Legal system, (iii) Cultural environment, (iv) Support of administrators, and (v) Professional qualifications of accountants to convert financial statements from VAS to IFRS. On that basis, the author proposes recommendations that need the support of state management agencies, training organizations, as well as implications for the administration of Vietnamese enterprises in the transformation of financial statements from VAS to IFRS. The results of this study have some similarities with the study of Parvathy (2017), De Lima et al. (2018).

Meanwhile, the study of Tran et al. (2019) on the factors affecting the application of IFRS in listed companies shows that the factors of return on equity (ROE), quality of audit activities, etc. affect the application of IFRS in enterprises. Along this line of research, the study of Ta et al. (2021) also shows that the factors ROE, audit quality, foreign investors, the form of organization also affect the application of IFRS in enterprises. Besides, the research of Nguyen et al (2020) also shows that the higher the profitability, debt ratio and enterprise size, the more likely that the successful application of IFRS will be than other enterprises and vice versa. The results of this study have some similarities with the study of Al-Shetwe (2021), Al-Sakini et al. (2021), Ta et al. (2021), etc. From the review of the above studies, it is shown that many factors are impacting the application of IFRS to enterprises of different sizes, different operating forms and different legal forms. However, the research team believe that regarding the transition from preparing financial statements according to national accounting standards (this study is according to Vietnam's Accounting Standards - VAS) to preparing financial statements according to international accounting standards, the successful application in a particular enterprise depends a lot on internal factors belonging to the enterprise such as the knowledge of IFRS of the accountants in the enterprise, the points of view of the enterprise administrators, the complexity of the organization and operations of the enterprise, etc. Therefore, the authors determine that this is the gap for our study. Then, the strength of this study is that the research is associated with the specific financial reporting process of the enterprise to consider the factors affecting the transition of financial reporting from national accounting standards to applying IFRS. 
Therefore, the research team believes that this study has a certain contribution to providing important scientific evidence to help enterprises in Vietnam identify the factors affecting the transformation of financial statements so that they have appropriate and effective preparation plans.

\section{Research Methodology}

\subsection{Research Procedure}

To carry out this study, the authors followed research steps illustrated by the following diagram:

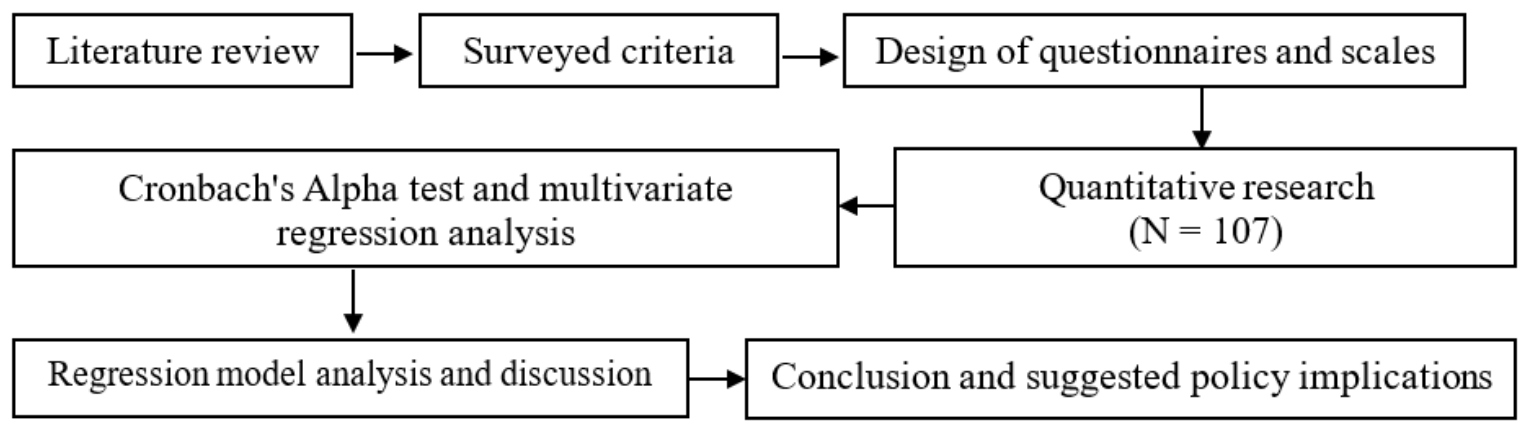

Fig. 1. Research procedure

\subsection{Research Hypotheses}

To carry out this study, the authors only focus on factors from inside the enterprise that affect the transition of financial statement preparation from VAS to IFRS, including factors and hypotheses for this study as follows:

\section{Competency of accountants (NL)}

Human resources are the most important factor that determines the success or failure of an enterprise in general. Therefore, applying IFRS to the accounting work of an enterprise will also be influenced by the enterprise's own accounting human resources, namely the professional qualifications of the accounting staff. If the accounting expertise of the enterprise accounting personnel does not meet the requirements for preparing financial statements under IFRS, the application of IFRS will not be possible or be implemented but inefficiently. Recent studies show that the conversion and application of IFRS require high skills, expertise in IFRS and English ability of accountants in enterprises (Shima \& Yang, 2012; Zakari, 2014; Istratea, 2015; Tran et al., 2019; Nguyen et al., 2020; Xuan, 2021; etc.).

Hypothesis H1: Accountants who have knowledge and expertise in IFRS have a positive influence on the transition of financial statement preparation from VAS to IFRS.

\section{Perspectives of enterprise administrators (QT)}

Administrators are the people who directly make the decisions to apply IFRS in the enterprise, so the administrators' understanding of IFRS and their decisions have an important influence on the application of IFRS in the enterprise. In addition, recent studies have shown that administrators' support in accessing transformation techniques, training accountants, and financial support for the transition also have positive and favourable effects on the transformation and application of IFRS in enterprises (Mulyadi et al., 2012; Türel, 2010; Evans \& Enahoro, 2014; Christensen et al., 2015; Tran et al., 2019; Ta et al., 2021; Xuan, 2021; etc.).

Hypothesis H2: Administrators with good IFRS knowledge have a positive influence on the transition of financial statement preparation from VAS to IFRS.

\section{Size and operational characteristics of the enterprise (QM)}

Enterprise size plays an important role, associated with the development strategy of the enterprise. When an enterprise has a large scale, the operational characteristics and business lines will be diversified; and to mobilize capital sources for operation and expansion, enterprises tend to rely heavily on external capital sources (liabilities). Accordingly, it is required that enterprises improve the quality of financial reporting information to be sent to the creditors, banks and potential investors; thus there will be a greater tendency to voluntarily apply IFRS than small scale enterprises. At the same time, when enterprises operate in multiple industries, the consolidation of financial statements will face more difficulties than enterprises operating in single industries. Recent studies also show that the size of the enterprise and the operational 
characteristics of the enterprise are influential factors on the voluntary choice of applying IFRS (Yang, 2014; Uzma, 2016; Nguyen, 2018; De Lima et al., 2018; Al-Shetwe, 2021; Xuan, 2021; etc.).

Hypothesis H3: The size and operational characteristics of the enterprise have a positive influence on the transition of financial statement preparation from VAS to IFRS.

\section{Applied accounting regime (CD)}

Currently, all of the enterprises in all fields and all economic sectors operating in Vietnam are applying VAS for the preparation and presentation of financial statements. However, the operation of VAS is increasingly revealing many limitations, some of which are not suitable for transactions of enterprises in the new period, especially in the context of the capital market developing strongly and the appearance of a variety of complex financial instruments. Recent studies have shown that accounting regime directly affects the presentation of information on financial statements of enterprises, as well as the quality of information on financial statements (Kim et al., 2010; Zakari, 2014; Uzma, 2016; Do \& Tran, 2017; Nguyen, 2018; Al-Sakini et al., 2021; etc.)

Hypothesis H4: The applied accounting regime has a positive effect on the transition of financial statement preparation from VAS to IFRS.

\section{Enterprise owners (CSH)}

Enterprise owners are organizations or individuals that have invested capital in an enterprise, which can be the state (for state enterprises), capital contributors (for limited liability companies), shareholders (for joint-stock companies), etc. When the owners invest in the enterprise, the owners are interested in the return on the invested capital, as well as the compliance with the corporate laws to avoid legal troubles potentially affecting the profitability and growth of the enterprise. Recent studies have shown that owners tend to require the organization of corporate accounting to follow the principle of nonemployment for activities with a high risk of fraud, as well as transparency and disclosure of information on financial statements (Noh \& Kim, 2015; Yuniarta \& Purnamawati, 2020; Kedzior et al., 2020; Al-Shetwe, 2021; etc).

Hypothesis H5: Enterprise owners have a positive influence on the transition of financial statement preparation from VAS to IFRS.

\subsection{Research Model}

Based on the research hypotheses, the authors propose the research model which is a multivariable regression model with the dependent variable being the transition of financial statement preparation from VAS to IFRS and 05 independent variables being stated in each hypothesis of the study:

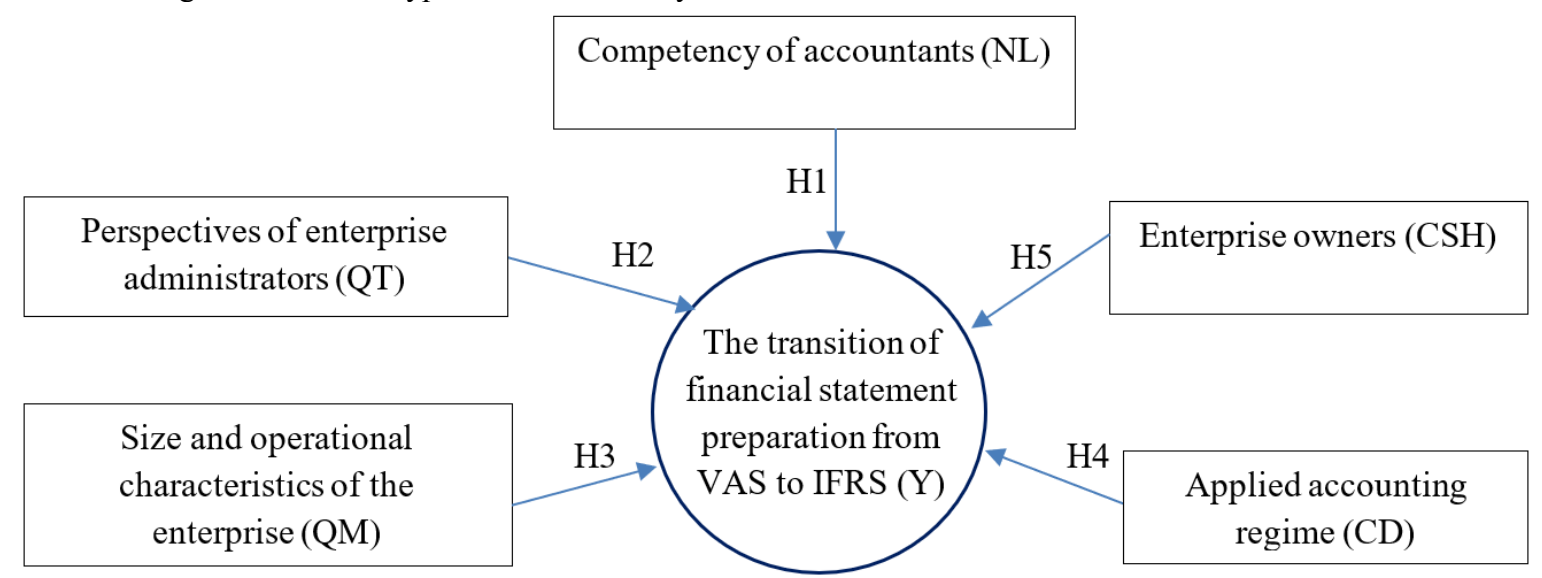

Fig. 2. Overview of the research model

From the above-proposed model, the authors propose the expected research equation as:

where:

$$
Y=\alpha+\beta_{1} \times N L+\beta_{2} \times Q T+\beta_{3} \times Q M+\beta_{4} \times C D+\beta_{5} \times C S H+\varepsilon
$$

$\alpha, \beta_{1}, \beta_{2}, \beta_{3}, \beta_{4}$ and $\beta_{5}$ are coefficients $\varepsilon$ : is error 


\subsection{Variables of the Research Model}

To serve the process of delivering and gathering the data, the authors used the Likert scale (5 options), the rating levels according to this scale are as follows: 1 - Strongly disagree; 2 - Disagree; 3 - Neutral; 4 - Agree; 5 - Strongly agree. The variables and scales of the research model are determined as follows:

Table 1

Variables and scales used

\begin{tabular}{|c|c|c|c|c|}
\hline Order & Factors & Observed variables & Encryption & Sources \\
\hline \multicolumn{5}{|c|}{ Dependent variable } \\
\hline \multirow{3}{*}{1} & \multirow{3}{*}{$\begin{array}{l}\text { The transition of } \\
\text { financial statement } \\
\text { preparation from } \\
\text { VAS to IFRS (Y) }\end{array}$} & $\begin{array}{l}\text { The information on the enterprise's financial statements will } \\
\text { change positively when the enterprise converts its financial } \\
\text { statements from VAS to IFRS }\end{array}$ & Y1 & \multirow{3}{*}{$\begin{array}{c}\text { The authors' proposition is } \\
\text { based on references: } \\
\text { Noh \& Kim (2015), Kim et } \\
\text { al. (2010), } \\
\text { Tran et al. (2019), Nguyen } \\
\text { et al. (2020), Kedzior et al. } \\
\text { (2020), } \\
\text { Xuan (2021), } \\
\text { Ta et al. (2021) }\end{array}$} \\
\hline & & $\begin{array}{l}\text { The way of preparing and presenting financial statements will } \\
\text { change when an enterprise converts its financial statements } \\
\text { from VAS to IFRS }\end{array}$ & $\mathrm{Y} 2$ & \\
\hline & & $\begin{array}{l}\text { When converting financial statements from VAS to IFRS, it } \\
\text { is to ensure that enterprises comply with the regulations of } \\
\text { the Ministry of Finance and are more likely to access } \\
\text { investment capital in the coming time }\end{array}$ & Y3 & \\
\hline \multicolumn{5}{|c|}{ Independent variables } \\
\hline \multirow{4}{*}{2} & \multirow{4}{*}{$\begin{array}{l}\text { Competency of } \\
\text { accountants }(\mathrm{NL})\end{array}$} & Accountants need to be trained and retrained in IFRS & NL2 & \multirow{4}{*}{$\begin{array}{c}\text { The authors' proposition is } \\
\text { based on references: } \\
\text { Shima \& Yang (2012), } \\
\text { Zakari (2014), Istratea } \\
\text { (2015), Tran et al. (2019), } \\
\text { Nguyen et al. (2020), Xuan } \\
\text { (2021) }\end{array}$} \\
\hline & & $\begin{array}{l}\text { Accountants have knowledge of IFRS and the preparation of } \\
\text { financial statements according to IFRS }\end{array}$ & NL1 & \\
\hline & & $\begin{array}{l}\text { Accountants need to be proficient in using accounting tools } \\
\text { according to IFRS }\end{array}$ & NL3 & \\
\hline & & $\begin{array}{l}\text { Accountants need to have good foreign language skills to be } \\
\text { able to read and comprehend IFRS standards }\end{array}$ & NL4 & \\
\hline \multirow{4}{*}{3} & \multirow{4}{*}{$\begin{array}{l}\text { Perspectives of } \\
\text { enterprise } \\
\text { administrators (QT) }\end{array}$} & $\begin{array}{l}\text { Administrators need to pay attention to the conversion of } \\
\text { preparing financial statements to IFRS to comply with } \\
\text { regulations }\end{array}$ & QT1 & \multirow{4}{*}{$\begin{array}{l}\text { The authors' proposition is } \\
\text { based on references: Türel } \\
\text { (2010), Mulyadi et al. } \\
\text { (2012), Evans \& Enahoro } \\
\text { (2014), Christensen et al. } \\
\text { (2015), Tran et al. (2019), } \\
\text { Ta et al. (2021), Xuan, } \\
\text { (2021) }\end{array}$} \\
\hline & & $\begin{array}{l}\text { Administrators with a full understanding of IFRS will support } \\
\text { the transition of preparing financial statements from VAS to } \\
\text { IFRS }\end{array}$ & QT2 & \\
\hline & & $\begin{array}{l}\text { The conversion of preparing financial statements from VAS } \\
\text { to IFRS needs financial support and human resource training }\end{array}$ & QT3 & \\
\hline & & $\begin{array}{l}\text { Administrators need to understand the work steps that need } \\
\text { to be prepared to convert the preparation of financial } \\
\text { statements from VAS to IFRS }\end{array}$ & QT4 & \\
\hline \multirow{3}{*}{4} & \multirow{3}{*}{$\begin{array}{c}\text { Size and } \\
\text { operational } \\
\text { characteristics of } \\
\text { the enterprise }(\mathrm{QM})\end{array}$} & $\begin{array}{l}\text { The size of the enterprise affects the transition of preparing } \\
\text { financial statements from VAS to IFRS }\end{array}$ & QM1 & \multirow{3}{*}{$\begin{array}{l}\text { The authors' proposition is } \\
\text { based on references: Yang } \\
(2014), \text { Uzma (2016), } \\
\text { Nguyen (2018), De Lima } \\
\text { et al. (2018), Al-Shetwe } \\
\text { (2021), Xuan (2021) }\end{array}$} \\
\hline & & $\begin{array}{l}\text { Operational characteristics of enterprises affect the transition } \\
\text { of preparing financial statements from VAS to IFRS }\end{array}$ & QM2 & \\
\hline & & $\begin{array}{l}\text { Mutual support is required between the parent company and } \\
\text { its member companies when converting the preparation of } \\
\text { financial statements to IFRS }\end{array}$ & QM3 & \\
\hline \multirow{3}{*}{5} & \multirow{3}{*}{$\begin{array}{l}\text { Applied accounting } \\
\text { regime }(\mathrm{CD})\end{array}$} & $\begin{array}{l}\text { Accounting regimes and applied accounting policies affect } \\
\text { the transition of preparing financial statements from VAS to } \\
\text { IFRS }\end{array}$ & CD1 & \multirow{3}{*}{$\begin{array}{l}\text { The authors' proposition is } \\
\text { based on references: } \\
\text { Zakari (2014), Uzma } \\
\text { (2016), Kim et al. (2010), } \\
\text { Nguyen (2018), Al-Sakini } \\
\text { et al. (2021) }\end{array}$} \\
\hline & & $\begin{array}{l}\text { The lack of regulations and guidance on the application of } \\
\text { IFRS issued by the Ministry of Finance affects the conversion } \\
\text { of preparing financial statements according to IFRS for } \\
\text { enterprises }\end{array}$ & $\mathrm{CD} 2$ & \\
\hline & & $\begin{array}{l}\text { There are many inconsistencies between VAS and IAS/IFRS } \\
\text { that hinder enterprises when converting the preparation of } \\
\text { financial statements }\end{array}$ & CD3 & \\
\hline \multirow{3}{*}{6} & \multirow{3}{*}{$\begin{array}{l}\text { Enterprise owners } \\
\quad(\mathrm{CSH})\end{array}$} & $\begin{array}{l}\text { The forms of enterprise owners (shareholders, capital } \\
\text { contributors, etc.) influence the transition of preparing } \\
\text { financial statements from VAS to IFRS }\end{array}$ & CSH1 & \multirow{3}{*}{$\begin{array}{l}\text { The authors' proposition is } \\
\text { based on references: Noh } \\
\text { \& Kim (2015), Yuniarta \& } \\
\text { Purnamawati (2020), } \\
\text { Kedzior et al. (2020), Al- } \\
\text { Shetwe (2021). }\end{array}$} \\
\hline & & $\begin{array}{l}\text { The owners' interest in the financial statements of the } \\
\text { enterprises affects the transition of preparing financial } \\
\text { statements from VAS to IFRS }\end{array}$ & $\mathrm{CSH} 2$ & \\
\hline & & $\begin{array}{l}\text { That the owners have a full understanding of IFRS will } \\
\text { accelerate the transition of preparing financial statements } \\
\text { from VAS to IFRS }\end{array}$ & $\mathrm{CSH} 3$ & \\
\hline
\end{tabular}

\subsection{Methods of Data Collection}

To collect data for the study, the authors used a pre-designed survey questionnaire based on the variables and scales identified. The final survey questionnaire was built based on 3 stages. 
Stage 1, Designing a draft survey questionnaire: the authors conducted a review of domestic and foreign studies related to the research problem to identify research gaps. Next, the research team designed a draft survey questionnaire consisting of two parts, specifically: (i) general information about respondents, and (ii) survey information.

Stage 2, Consulting experts and conducting experimental investigations to complete the scales, observed variables, etc. to be surveyed: at this stage, the authors conducted direct interviews with experts who are enterprise administrators, lecturers at universities and experts working at professional organizations such as the Association of Chartered Certified Accountants (ACCA), Vietnam Association of Accountants and Auditors (VAA) with the interviews and consultations of 20 people. At this stage, the research team conducted direct interviews about the survey questionnaires designed in stage 1 and discussed research ideas with experts and lecturers to check whether the survey questionnaire is appropriate or not, whether it is necessary to add or adjust the observed scales and variables accordingly.

Stage 3, Designing official survey questionnaire: based on the interview results in stage 2, the authors synthesized and issued a complete survey questionnaire. To increase the effectiveness, accuracy and feasibility of the survey, the authors sent the survey questionnaires back to the experts for further review and additional comments (if any), which is to complete the final survey questionnaire as best as possible.

Similarly, according to Hair et al. (2010), for Exploratory Factor Analysis (EFA) with a sample size of 5:1 applied, the sample size needed for this study is $20 \times 5=100$ samples; and for multivariable regression analysis, the sample size needed for this study is $50+8 \times 5=90$ samples. Therefore, to ensure the number of samples for the study, the authors sent a survey to 120 enterprises, including 40 listed on the Ho Chi Minh City Stock Exchange, 40 listed on the Hanoi Stock Exchange, and 40 enterprises with state capital holding the dominant power through the Google Form. The survey results obtained 107 valid responses, reaching the response rate of $89.16 \%$, the number of votes collected reached the required survey sample size for the study. Therefore, the number of official survey samples to include in testing and data analysis of this study is 107 samples.

\subsection{Methods of Data Analysis}

From the survey handouts validly collected, the authors transferred data to Excel, coding variables for each part of the survey. Next, all of the data were put into SPSS 22.0 software. The authors conducted different analyses and testing, for analyzing data, on SPSS software as follows:

Cronbach's Alpha analysis: The purpose of Cronbach's Alpha analysis is to test the reliability of the scale and survey data to evaluate the correlation between the observed variables that are the influencing factors in the survey to see if the observed variables are closely related to one another in measuring the impact level of test factors on the development of sustainable tourism. Most researchers accept Cronbach's Alpha's 0.8 or higher as good; 0.7 to 0.8 is usable and if the concepts in question are new then the coefficient should be just above 0.6. With Cronbach's Alpha level greater than or equal to 0.8, the scale is considered a good measure, the questions are closely designed, the scales are correlated to achieve high reliability (Hoang \& Chu, 2011).

Exploratory factor analysis (EFA): When analyzing discovery factors, researchers are concerned about certain standards. First, Kaiser-Meyer-Olkin (KMO) coefficient $\geq 0.5$, the significance level of the Bartlett $\leq 0.05$ test. KMO is a criterion used to consider the appropriateness of EFA, $0.5 \leq \mathrm{KMO} \leq 1$, then factor analysis is appropriate. Bartlett's Test examined the hypothesis of the correlation between zero observed variables overall. If this test is statistically significant (Sig $\leq 0.05)$, the observed variables are correlated overall.Second, factor loading coefficient $>0.45$. If any observed variable has a factor loading coefficient $\leq 0.45$, it will be disqualified. Third, the scale is accepted when the total variance extracted is $\geq 50 \%$ and the eigenvalue is greater than 1. Fourth, there must be a difference in factor loading coefficient of an observed variable among factors $\geq 0.3$ to ensure the distinguishing value among factors is protected (Hoang \& Chu, 2011). According to Dinh et al. (2018), factor loading is the norm to ensure the practical meaning of EFA. Factor loading $>0.3$ is considered to be the minimum, factor loading $>0.4$ is considered important, factor loading $\geq 0.5$ is considered to have practical significance.

Correlation and regression analysis: The authors used the methods of correlation analysis and linear regression to test the linear correlation between the dependent variable and the independent variables. The correlation analysis used for this study is the Pearson correlation, which has a value ranging from -1 to 1 , and the research hypothesis will be accepted correctly if the significance level (sig) is < 0.05 (Hoang \& Chu, 2011; Dinh et al., 2018).

\section{Research Results}

\subsection{Cronbach's Alpha}

In this study, the observed variables of the independent and dependent variables are selected when the Cronbach's Alpha coefficients are 0.6 or higher and the total variable correlation is greater than 0.3 . The results shown in Table 2 demonstrate that the variables in the research model are reliable. 
Test results also show that Cronbach's Alpha of the dependent and independent variables are both greater than 0.6. Thus, both the dependent variables and the independent variables are satisfactory in terms of reliability, so no variable is removed. Hence, the test results of the scales show that all scales are consistent and reliable, and statistically significant to use the EFA discovery factor analysis.

Table 2

The Cronbach's Alpha coefficient of the independent variable and the dependent variable

\begin{tabular}{lll}
\hline Reliability Statistics & $\begin{array}{l}\text { Number of } \\
\text { items }\end{array}$ & $\begin{array}{l}\text { Cronbach's } \\
\text { Alpha }\end{array}$ \\
\hline 1. Competency of accountants (NL) & 4 & 0.754 \\
2. Perspectives of enterprise administrators (QT) & 4 & 0.768 \\
3. Size and operational characteristics of the enterprise (QM) & 3 & 0.671 \\
4. Applied accounting regime (CD) & 3 & 0.697 \\
5. Enterprise owners (CSH) & 3 & 0.752 \\
6. The transition of financial statement preparation from VAS to IFRS (Y) & 3 & 0.852 \\
\hline
\end{tabular}

\subsection{Exploratory Factor Analysis (EFA)}

Based on testing reliability and correlation by Cronbach's Alpha, the authors analyzed the EFA discovery factor, and the results are as follows:

According to the KMO table and Bartlett's test, we have the KMO coefficient $=0.852>0.5$ (greater than the minimum to ensure proper EFA analysis) and the Sig level of Bartlett's test is $0.000<0.05$, which means that the variables correlate in general. Thus, the EFA analysis for the independent variables is significant. The analytical results in Table 3 show that according to the Eigenvalue $>1$ standard, 05 groups of factors were drawn. The total variance extracted is $71.540 \%$ (greater than the standard level $>50 \%$ ), which means $71.540 \%$ variation of the data is explained by 05 groups of factors.

Table 3

The results of total variation of the data

\begin{tabular}{ccccccc}
\hline \multirow{2}{*}{ Component } & \multicolumn{3}{c}{ Initial Eigenvalues } & \multicolumn{2}{c}{ Extraction Sums of Squared Loadings } \\
\cline { 2 - 7 } & Total & \% of Variance & Cumulative \% & Total & \% of Variance & Cumulative \% \\
\hline 1 & 8.002 & 44.453 & 44.453 & 8.002 & 44.453 & 44.453 \\
2 & 2.111 & 11.729 & 56.181 & 2.111 & 11.729 & 56.181 \\
3 & 1.575 & 8.751 & 64.933 & 1.575 & 8.751 & 64.933 \\
4 & 1.293 & 6.156 & 66.887 & 1.293 & 6.156 & 66.887 \\
5 & 1.189 & 6.608 & 71.540 & 1.189 & 6.608 & 71.540 \\
6 & 0.896 & 4.979 & 76.519 & & & \\
\hline
\end{tabular}

Besides, when using Varimax rotation to obtain the best load factor, 05 groups of influencing factors were obtained, including: (1) Size and operational characteristics of the enterprise (3 variables); (2) Applied accounting regime (3 variables); (3) Competency of accountants (4 variables); (4) Perspectives of enterprise administrators (4 variables); (5) Enterprise owners (3 variables) (see Table 4).

Table 4

The factor transformation matrix of independent variables

\begin{tabular}{|c|c|c|c|c|c|}
\hline & \multicolumn{5}{|c|}{ Component } \\
\hline & 1 & 2 & 3 & 4 & 5 \\
\hline QM1 & 0.785 & & & & \\
\hline QM2 & 0.732 & & & & \\
\hline QM3 & 0.759 & & & & \\
\hline CD1 & & 0.781 & & & \\
\hline $\mathrm{CD} 2$ & & 0.771 & & & \\
\hline CD3 & & 0.747 & & & \\
\hline NL1 & & & 0.817 & & \\
\hline NL2 & & & 0.556 & & \\
\hline NL3 & & & 0.610 & & \\
\hline NL4 & & & 0.707 & & \\
\hline QT1 & & & & 0.813 & \\
\hline QT2 & & & & 0.717 & \\
\hline QT3 & & & & 0.794 & \\
\hline QT4 & & & & 0.598 & \\
\hline CSH1 & & & & & 0.804 \\
\hline $\mathrm{CSH} 2$ & & & & & 0.769 \\
\hline $\mathrm{CSH} 3$ & & & & & 0.569 \\
\hline
\end{tabular}

Extraction Method: Principal Component Analysis. 
At the same time, for the dependent variable, the transition of financial statement preparation from VAS to IFRS (Y), according to the KMO table and Bartlett's test, we have the KMO coefficient $=0.712>0.5$ (greater than the minimum to ensure proper EFA analysis) and the Sig level of Bartlett's test is $0.000<0.05$, which means that the variables correlate in general. Thus, the EFA analysis for the dependent variables is significant. The analytical results in Table 5 show that according to the Eigenvalue $>1$ standard, 01 group of factors was drawn. The total variance extracted is $79.740 \%$ (greater than the standard level $>50 \%$ ), which means $79.740 \%$ variation of the data is explained by 01 group of factors.

Table 5

The factor transformation matrix of the dependent variable

\begin{tabular}{ccccccc}
\hline \multirow{2}{*}{ Component } & \multicolumn{3}{c}{ Initial Eigenvalues } & \multicolumn{2}{c}{ Extraction Sums of Squared Loadings } \\
\cline { 2 - 7 } & Total & \% of Variance & Cumulative \% & Total & \% of Variance & Cumulative \% \\
\hline 1 & 2.489 & 79.740 & 79.740 & 2.489 & 79.740 & 79.740 \\
2 & 0.301 & 13.257 & 92.897 & & & \\
\hline
\end{tabular}

Extraction Method: Principal Component Analysis.

\subsection{Regression Analysis}

After conducting the EFA analysis, the next step is to conduct correlation analysis and regression analysis. In this study, the authors conducted Pearson correlation analysis intending to check the close linear correlation between the dependent variable and the independent variables, because the condition for regression is the correlation.

Table 6

Pearson Correlation Analysis results

\begin{tabular}{llcccccc}
\hline & QM & CD & NL & QT & CSH & Y \\
\hline \multirow{2}{*}{ QM } & Pearson Correlation & $\mathbf{1 . 0 0 0}$ & $0.383^{* *}$ & $0.427^{* *}$ & $0.388^{* *}$ & $0.414^{* *}$ & $0.371^{* *}$ \\
& Sig. (2-tailed) & & 0.000 & 0.000 & 0.000 & 0.000 & 0.000 \\
& N & 107 & 107 & 107 & 107 & 107 & 107 \\
\hline \multirow{2}{*}{ CD } & Pearson Correlation & $0.383^{* *}$ & $\mathbf{1 . 0 0 0}$ & $0.380^{* *}$ & $0.355^{* *}$ & $0.235^{*}$ & 0.155 \\
& Sig. (2-tailed) & 0.000 & & 0.000 & 0.000 & 0.003 & 0.001 \\
& N & 107 & 107 & 107 & 107 & 107 & 107 \\
\hline \multirow{3}{*}{ NL } & Pearson Correlation & $0.427^{* *}$ & $0.380^{* *}$ & $\mathbf{1 . 0 0 0}$ & $0.406^{* *}$ & $0.418^{* *}$ & $0.452^{* *}$ \\
& Sig. (2-tailed) & 0.000 & 0.000 & & 0.000 & 0.000 & 0.000 \\
& N & 107 & 107 & 107 & 107 & 107 & 107 \\
\hline \multirow{4}{*}{ QT } & Pearson Correlation & $0.388^{* *}$ & $0.355^{* *}$ & $0.406^{* *}$ & $\mathbf{1 . 0 0 0}$ & $0.407^{* *}$ & $0.369^{* *}$ \\
& Sig. (2-tailed) & 0.000 & 0.000 & 0.000 & & 0.000 & 0.000 \\
& N & 107 & 107 & 107 & 107 & 107 & 107 \\
\hline \multirow{2}{*}{ CSH } & Pearson Correlation & $0.414^{* *}$ & $0.235^{*}$ & $0.418^{* *}$ & $0.407^{* *}$ & $\mathbf{1 . 0 0 0}$ & $0.389^{* *}$ \\
& Sig. (2-tailed) & 0.000 & 0.003 & 0.000 & 0.000 & 107 & 0.000 \\
& N & 107 & 107 & 107 & 107 & 107 & 107 \\
\hline \multirow{2}{*}{ Y } & Pearson Correlation & $0.371^{* *}$ & 0.155 & $0.452^{* *}$ & $0.369^{* *}$ & $0.389^{* *}$ & $\mathbf{1 . 0 0 0}$ \\
& Sig. (2-tailed) & 0.000 & 0.001 & 0.000 & 0.000 & 0.000 & 107 \\
\hline
\end{tabular}

The results of the correlation analysis between the independent variables and the dependent variable shows that the sig values are all $<0.05$, the Pearson correlation coefficients are $>0$, proving that there is a positive correlation between the independent and dependent variables. Next, the authors conducted a regression analysis, to perform regression analysis, the authors calculated the mean value to represent the dependent variables and the independent variables. The results of the regression analysis are as follows:

Table 7

The results of Regression Analysis

\begin{tabular}{|c|c|c|c|c|c|c|c|c|}
\hline & \multicolumn{2}{|c|}{$\begin{array}{c}\text { Unstandardized } \\
\text { Coefficients }\end{array}$} & \multirow{2}{*}{$\begin{array}{c}\begin{array}{c}\text { Standardized } \\
\text { Coefficients }\end{array} \\
\text { Beta } \\
\end{array}$} & \multirow[b]{2}{*}{$\mathbf{t}$} & \multirow[b]{2}{*}{ Sig. } & \multicolumn{2}{|c|}{ Collinearity Statistics } \\
\hline & & \multirow{2}{*}{$\begin{array}{c}\text { B } \\
-.492\end{array}$} & \multirow{2}{*}{$\begin{array}{c}\text { Std. Error } \\
0.184\end{array}$} & & & & Tolerance & $\begin{array}{c}\text { Itistics } \\
\text { VIF }\end{array}$ \\
\hline \multirow[t]{6}{*}{1} & Model & & & & -2.680 & \multicolumn{3}{|l|}{0.001} \\
\hline & $\mathrm{QM}$ & 0.493 & 0.064 & 0.466 & 7.721 & 0.000 & 0.421 & 1.374 \\
\hline & CD & \multirow{2}{*}{$\begin{array}{l}0.035 \\
0.343\end{array}$} & 0.039 & 0.033 & 0.890 & 0.000 & 0.655 & 1.527 \\
\hline & NL & & 0.069 & 0.285 & 4.937 & 0.002 & 0.227 & 2.399 \\
\hline & QT & 0.276 & 0.079 & 0.239 & 3.517 & 0.000 & 0.345 & 1.895 \\
\hline & $\mathrm{CSH}$ & 0.020 & 0.043 & 0.019 & 0.470 & 0.004 & 0.283 & 2.534 \\
\hline
\end{tabular}

a. Dependent Variable: Y 
Table 7 shows that all the independent variables affect the dependent variables for the transition of financial statement preparation from VAS to IFRS (Y) (this is concluded through the T-test with Sig level of the Test less than 1\% and 5\%). Also, the problem of multi-collinearity does not appear in the model. Specifically, the VIF magnification coefficients are all less than 10 (the level is determined with multiple collinearities to be treated).

$\mathrm{R}^{2}$ of the model is $77.2 \%$, proving that the independent variables can explain the high volatility of the dependent variables. Besides, the results of testing the conformity of the regression function through F statistics from the ANOVA table showed that the model was suitable (the Sig level of the test is very small 0.000). Thus, based on the regression results table, we have a regression equation for factors affecting the transition of financial statement preparation from VAS to IFRS:

$Y=-0.492+0.493 \times Q M+0.035 \times C D+0.343 \times N L+0.276 \times Q T+0.020 \times C S H$

The standardized regression model is defined as follows:

$Y=0.466 \times Q M+0.033 \times C D+0.285 \times N L+0.239 \times Q T+0.019 \times C S H$

According to the standardized regression model, the QM factor has a strong impact on the transition of financial statement preparation from VAS to IFRS (with the standardized beta coefficient of 0.466), followed by NL and QT with standardized beta numbers is 0.285 and 0.239 . The lowest influence on the dependent variable is the CD and CSH factors (with standardized beta coefficients of only 0.033 and 0.019 ).

\section{Discussion and Policy Implications}

From the results of the regression analysis, an interesting relationship can be found. Specifically, the size and operational characteristics of the enterprise, the competency of the accountants and the perspectives of the enterprise administrators significantly affect the conversion of preparing financial statements from VAS to IFRS. The results of this study are similar to those of Shima \& Yang (2012), Zakari (2014), Tran et al. (2019), Nguyen et al. (2020), Xuan (2021), Ta et al. (2021). However, the study also shows that in the context of Vietnam, the issues of accounting regime applied and ownership form have an impact on the transition of preparing financial statements from VAS to IFRS but is not significant. The results of this study are somewhat different from those of Zakari (2014), Noh \& Kim (2015), Uzma (2016), Kim et al. (2010), Nguyen (2018), Kedzior et al. (2020). This illustrates that, in Vietnam, to convert the preparation of financial statements from VAS to IFRS, it is necessary to focus on the issues related to the size and operational characteristics of the enterprise, and the competency of accounting employees, and the perspectives of enterprise administrators. On that basis, the study suggests that to convert the preparation of financial statements from VAS to IFRS, enterprises in Vietnam need to do the following actions:

\section{First, about the size and operational characteristics of the enterprise (QM)}

According to the application roadmap of the Ministry of Finance, large-scale enterprises such as listed companies, stateowned corporations and corporations holding the controlling capital are encouraged to apply IFRS from 2022 and will start the compulsory application of IFRS from 2025. Therefore, it has been shown that the results of this study are consistent with the roadmap for IFRS application of the Ministry of Finance. To apply IFRS, enterprises are required to agree on accounting methods, accounting recording methods, presentation of accounting information, etc. for accounting operations with shared characteristics between the parent company and its member companies to facilitate the consolidation of accounting figures on the consolidated financial statements. Particularly for member enterprises with different business activities from the parent company and other companies in the group, consolidation is required to clarify the overall picture of the financial position and business results of the group in the consolidated financial statements. Therefore, there is a need for mutual support between the parent company and its member companies, as well as a need for accounting guides in the member units on the technique of recording and presenting information in the financial statements under IFRS during the transition of financial statement preparation to IFRS and the consolidation of financial statements.

\section{Second, about the competency of accountants (NL)}

The process of actual survey and interview with chief accountants at the surveyed enterprises also shows that the majority of accounting staff working in enterprises today are fully trained under VAS. Only a small number of accountants in some enterprises have self-trained in IFRS knowledge to serve their professional work, which is mainly the case in foreigninvested enterprises. The understanding of IFRS by accountants in enterprises is currently very limited. Therefore, the Ministry of Finance of Vietnam should issue policies to support training and fostering of IFRS knowledge for accounting staff of the enterprises which are entitled to IFRS application according to the issued roadmap. Besides, training should also be offered to the teaching staff of the universities and colleges with accounting majors to serve the IFRS knowledge training for accounting personnel in the coming time. The Ministry of Finance can coordinate with international professional organizations such as ACCA, ICAEW, etc. to support training through IFRS knowledge training in person or on online platforms, namely Zoom, Google Meet, Youtube, etc., to widely disseminate IFRS knowledge to the majority of enterprises 
conveniently and effectively. At the same time, in addition to the support of the Ministry of Finance, enterprises also need to actively nominate their accountants to participate in IFRS courses organized by professional organizations to improve the capacity of English for accounting staff, which is towards the aim that the accountants can easily read, understand and apply accounting tools according to IFRS for effective financial statement preparation.

\section{Third, about the perspectives of enterprise administrators (QT)}

Enterprise administrators need to be aware that the conversion of financial statement preparation to IFRS is mandatory by law, and that the preparation of financial statements according to IFRS will help enterprises enhance the quality of the information on financial statements to make it easier to access investment capital, especially from investment funds and multinational companies. Therefore, the administrators of enterprises themselves also need to have a certain understanding of IFRS to run the enterprise, to pay attention to creating favourable policies for the application of IFRS in enterprises, to provide financial support and the necessary conditions for the transition to financial statement preparation following IFRS.

Fourth, about the applied accounting regime (CD)

Subsidiaries or affiliated units in the same parent company or corporation need to have consistency in the application of accounting standards, accounting regimes and accounting methods for the transition to IFRS is uniform in the compilation of accounting data and the preparation of financial statements.

\section{Fifth, about Enterprise owners (CSH)}

Enterprise owners need to increase the pressure on managers and business operators about the need to convert financial reporting to IFRS to promote the transition faster, so that soon directly and indirectly benefit enterprise owners from this transition.

\section{Conclusion}

This study shows that the conversion of financial statement preparation from VAS to IFRS in enterprises in Vietnam is influenced by the factors related to the size and operational characteristics of enterprises, competency of accountants in enterprises, the perspectives of enterprise administrators, the applied accounting regime and the form of enterprise owners. Among the factors mentioned above, it is worth noting that the factors of the size and operational characteristics of the enterprise, the capacity of the accountants in the enterprises, the perspectives of the enterprise administrators are the factors that have a significant influence; while the factors of applied accounting regime and form of enterprise owners are influential but insignificant. On that basis, the study suggests a number of policy implications that should be examined to meet the Ministry of Finance's roadmap for IFRS application. It can be said that this study makes an important scientific contribution to identifying factors affecting the transition of financial statement preparation from VAS to IFRS in enterprises in Vietnam from the perspective of association with the financial statement preparation process. However, the study also has its limitations; the surveyed enterprises are not so diverse and have not covered all groups of enterprises that will apply IFRS in the near future. Besides, the study only focuses on the factors inside the enterprise but not on those outside the enterprise.

\section{Acknowledgement}

This research is funded by Van Lang University, Hochiminh, Vietnam.

\section{References}

Ajibade, A. T., Okere, W., Isiaka, M. A., \& Mabinuori, O. (2019). International Financial Reporting Standard (IFRS) Adoption and Foreign Direct Investments (FDI): A Comparative Analysis of Nigeria and Ghana. Asian Journal of Economics, Business and Accounting, 11(2), 1-10.

Al-Shetwi, M. (2021). Determinants of corporate social disclosure in Saudi Arabia: The role of social values and IFRS convergence. Accounting, 7(7), 1769-1778. http://dx.doi.org/10.5267/j.ac.2021.4.020

Al-Sakini, S., Awawdeh, H., Awamleh, I \& Qatawneh, A. (2021). Impact of IFRS (9) on the size of loan loss provisions: An applied study on Jordanian commercial banks during 2015-2019. Accounting, 7(7), 1601-1610. http://dx.doi.org/10.5267/j.ac.2021.5.010

Christensen, H. B., Lee, E., Walker, M. \& Zeng, C. (2015). Incentives or Standards: What Determines Accounting Quality Changes around IFRS Adoption?. Europe accounting review, 24, 31-61. https://doi.org/10.1080/09638180.2015.1009144

De Lima, V. S., De Lima, G. A. S. F., \& Gotti, G. (2018). Effects of the adoption of IFRS on the credit market: evidence from Brazil. The International Journal of Accounting, 53(2), 77-101. https://doi.org/10.1016/j.intacc.2018.04.001 
Dinh, P. H., Vo, V. N., \& Tran, P. (2018). Quantitative research in Accounting: Auditing. Hanoi, Vietnam: Financial Publishing House.

Do, D. T., \& Tran, T. D. (2017). The influence of cultural factors on the difference in financial statements of FDI enterprises according to Vietnamese and international accounting. Proceedings of the national scientific conference: Accounting Auditing and Vietnam's economy with the industrial revolution 4.0, November 2017. Quy Nhon University.

Evans, O., \& Enahoro, J. A. (2014). Comparative study of the international financial reporting standard implementation in Ghana and Nigeria. European Scientific Journal, 10(13), 1857 - 7881

Hair, J. F., Black, W. C., Babin, B. J., \& Anderson, R. E. (2010). Multivariate Data Analysis. 7th ed. Upper Saddle River, New Jersey: Prentice-Hall.

Hoang, T., \& Chu, N. M. N. (2011). Applied statistics in the social-economic analysis. Hanoi, Vietnam: Labour and Social Publishing House

Istratea, C. A. (2015). Information Systems on the impact of the transition to IFRS in the current legislative changes in Romania. International Journal of Information Technology \& Computer, 19, 1 -15.

Kim, J., Tsui, J., \& Yi, C. (2010). The voluntary adoption of International Financial Reporting Standards and loan contracting around the world. Review of Accounting Studies, 16(4), 779-811. http://dx.doi.org/10.1007/s11142-0119148-5

Kedzior, M., Cyganska, M., \& Syrrakos, D. (2020). Determinants of Voluntary International Financial Reporting Standards Adoption in Poland. Inzinerine Ekonomika-Engineering Economics, 31(2), $155-168$. http://dx.doi.org/10.5755/j01.ee.31.2.24603

Ministry of Finance (2016). Decision No. 345/QD-BTC on approving the Scheme on the application of financial reporting standards in Vietnam, issued on March 16, 2020. Hanoi.

Mulyadi, M. S., Soepriyanto, G., \& Anwar, Y. (2012). FRS adoption and taxation issue. International Journal of Arts and Commerce, 1(7), 159-165.

Noh, G-K., \& Kim, D-II. (2015). The Impact of K-IFRS Adoption on Accounting Conservatism: Focus on Distribution Companies. Journal of Distribution Science, 13(9), 95-101. http://dx.doi.org/10.15722/jds.13.9.201509.95

Nguyen, T. L. H., Le, T. H. P., Dao, N. M., \& Pham, N. T. (2020). Factors affecting enterprises that apply the International Financial Report Standards (IFRS): A case study in Vietnam. Journal of Asian Finance, Economics, and Business, 7(12), 409-422.

https://doi.org/10.13106/jafeb.2020.vol7.no12.409

Nguyen, N. H. (2018). Converting financial statements from Vietnamese accounting standards to international financial reporting standards - Empirical research in Vietnamese enterprises. Doctoral Thesis in Economics. University of Economics Ho Chi Minh City.

Owusu, G. M. I., Saat, N. A. M., Suppiah, S. D. K., \& Law, S. H. (2017). IFRS Adoption, Institutional Quality and Foreign Direct Investment Inflows: A Dynamic Panel Analysis. Asian Journal of Business and Accounting, 10(2), 43-75.

Parvathy, P. R. (2017). IFRS convergence: opportunities and challenges in India. Accounting and Financial Control, 1(2), 13-18. http://dx.doi.org/10.21511/afc.01(2).2017.02

Shima, K. M., \& Yang, D. C. (2012). Factors affecting the adoption of IFRS. International Journal of Business, 17(3), 276298.

Ta, T. T., Pham, D. C., Nguyen, H. A., Doan, T. N., Dinh, T. H., Do, H. G., \& Pham, H. T. (2021). Factors Affecting the Adoption of IFRS: The Case of Listed Companies on Ho Chi Minh Stock Exchange. Journal of Asian Finance, Economics and Business, 8(2), 873-882. https://doi:10.13106/jafeb.2021.vol8.no2.0873

Türel, A. (2010). The value relevance of IFRS: The case of Turkey. Finance and Banking, 5(1), 119-128.

Tran, M. D., \& Nguyen, T. H. (2016). Teaching IFRS in accounting training. Journal of Accounting \& Auditing, 150, 1517.

Tran, T., Ha, X., Le, T., \& Nguyen, N. (2019), Factors affecting IFRS adoption in listed companies: Evidence from Vietnam. Management Science Letters, 9(13), 2169-2180. https://doi. org/10.5267/j.msl.2019.7.035.

Uzma, S. H. (2016). Cost-benefit analysis of IFRS adoption: Developed and emerging countries. Journal of Financial Reporting and Accounting, 14(2), 198-229. https://doi.org/10.1108/JFRA-01-2015-0019

Ugwu, J. I., \& Udeh, S. N. (2018). Influence of Foreign Direct Investment on Exchange Rate and Domestic Investment in Pre- and Post- IFRS Adoption Periods of Selected Sub-Saharan African Countries (1999-2015). International Journal of Academic Research in Accounting, Finance and Management Sciences, 8(3), 1-16

Xuan, V. (2021). Determinants of business performance of the firms: A case of the construction listed enterprises in Vietnam Stock Market. Accounting, 7(7), 1741-1750. http://dx.doi.org/10.5267/j.ac.2021.4.023

Yang, D. (2014). Exploring the determinants of voluntary adoption of IFRS by unlisted firms: A comparative study between the UK and Germany. China Journal of Accounting Studies, 2(2), 118-136. https://doi:10.1080/21697221.2014.917030.

Yuniarta, G. A., \& Purnamawati, G. A. (2020). Key elements of local government transparency in new public governance. Problems and Perspectives in Management, 18(4), 96-106. doi:10.21511/ppm.18(4).2020.09

Zakari, M. A. (2014). Challenges of International Financial Reporting Standards (IFRS) Adoption in Libya. International Journal of Accounting and Financial Reporting, 4(2), 1-23. Available at http://dx.doi.org/10.2139/ssrn.2538220 
(C) 2022 by the authors; licensee Growing Science, Canada. This is an open access article distributed under the terms and conditions of the Creative Commons Attribution (CC-BY) license (http://creativecommons.org/licenses/by/4.0/). 